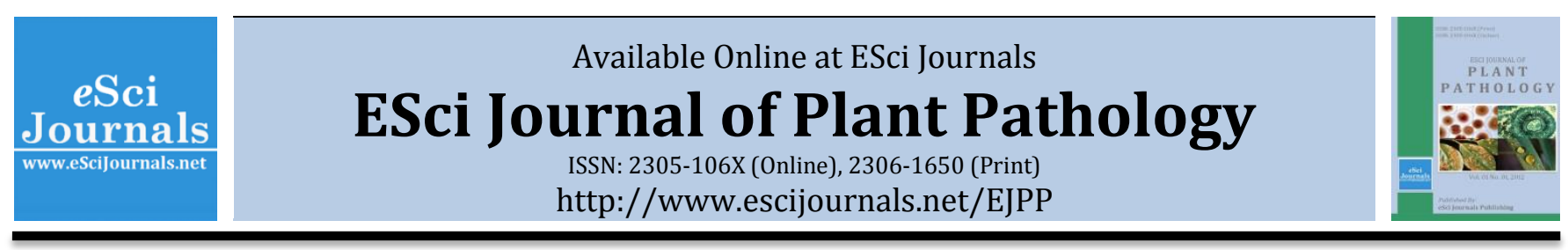

\title{
THE POTENTIAL OF FIVE ECO-BIORATIONAL PRODUCTS ON THE REPRODUCTION OF ROOT-KNOT NEMATODE AND PLANT GROWTH
}

\author{
Mohamed S. Khalil* \\ Central Agricultural Pesticides Laboratory, Agricultural Research Center, El-Sabaheya, Alexandria, Egypt.
}

\section{A B S T R A C T}

This work aimed to select potentially useful eco-biorational product that could be used to reduce the reproduction of root-knot nematode. The experiment was carried out in pots under net house. The results revealed that the bioproduct Dipel ${ }^{\circledR}$ (Bacillus thuringiensis ) proved to be the most effective treatment that reduced the root galls and egg masses by 71.60 and $77.78 \%$, respectively. Also, Dipel ${ }^{\circledR}$ (B. thuringiensis) \& Bio-nematon ${ }^{\circledR}$ (Paecilomyces lilacinus) showed their superiority between all treatments on the shoot, root length and root weight.

Keywords: Meloidogyne spp., antagonistic fungi, antagonistic bacteria, fosthiazate and nematodes management.

\section{INTRODUCTION}

Tomato plant (Solanum lycopersicum) is an important vegetable crop for nutritive sources such as carbohydrates, minerals and vitamins in Egypt (Howeedy et al., 2003). The most serious problems that threaten cultivated tomatoes are pests and diseases. The plant parasitic nematodes (PPN) have been found to be the most common and destructive diseases in the last two decades, and one of the most difficult plant diseases to control. The latest statistics showed that the estimated losses induced by PPN were $\$ 118$ billion worldwide (Atkinson et al., 2012).

There are thousands of nematodes genuses, but the most destructive genus around the world is the root-knot nematodes (Meloidogyne spp.). Meloidogyne spp can parasite on more than 2000 host species including vegetables, fruit trees, oil crops, fiber crops, grains crops and leguminous crops, next to weeds which is considered secondary host to nematodes (Khalil, 2013a). The most well-known species of root-knot nematode are Meloidogyne incognita, M. javanica, M. arenaria and $M$. hapla, which are responsible for high economic losses to varied crops. A number of methods for the root-knot nematodes management have been applied, and different levels of successes were displayed on crop * Corresponding Author:

Email: melonema@gmail.com

(c) 2013 ESci Journals Publishing. All rights reserved. protection (Randhawa et al., 2001 \& Sakhuja and Jain 2001). It was necessary to find alternatives and / or new approaches to manage and eliminate the plant nematodes diseases. The soil-inhabiting fungus Paecilomyces lilacinus (Thom) Samson (Eurotiales: Trichocomaceae) is capable of parasitizing nematode eggs, juveniles and females resulting in reduced soil population densities of plant parasitic nematodes (Atkins et al., 2005 and Khalil et al., 2012b). Furthermore, Trichoderma spp. plays major roles in controlling the plant diseases in roots, soil and foliar environments (Thangavelu and Mustaffa, 2012).

Also, the bacterium Bacillus thuringiensis Berliner produces parasporal crystalline proteinaceous inclusions. Most of these crystal proteins or $\delta$ endotoxins are toxic to larvae of lepidopteran, dipteran or coleopteran insects (Knowles and Dow, 1993), pathogenic protozoa, mites and nematodes (Fettelson et al., 1992). Meanwhile, it was reported that some strains of Bacillus subtilis have exhibited enormous potential as biocontrol agents in the management of root-knot nematodes (Karanja et al., 2007). Therefore, the objective of this study was to testify the efficiency of the commercial products as an alternative nematicides.

\section{MATERIALS AND METHODS}

The tested products:

The following tested eco-biorational products against the RKN (root knot nematode) were used: 
- Nemathorin ${ }^{\circledR} 10 \% \mathrm{G}$ (fosthiazate), [RS-S-sec-butyl $O$-ethyl 2-oxo-1, 3-thiazolidin-3-yl phosphonothioate; $(R S)$-3[sec-butylthio(ethoxy)phosphinoyl]-1,3-thiazolidin-2-one.

- Bio-Nematon ${ }^{\circledR} 1.15 \%$ WP, contains $1 * 10^{8} \mathrm{cfu} / \mathrm{g}$ of fungus (Paecilomyces lilacinus).

- Bio Zeid ${ }^{\circledR} 2.5 \% \mathrm{WP}$, contains $1 \times 10^{7}$ cell / g of fungus (Trichoderma album).

- Stanes sting ${ }^{\circledR}$ contains $1 * 10^{9} \mathrm{cell} / \mathrm{ml}$ of bacterium (Bacillus subtilis).

- Bio $\operatorname{Arc}^{\circledR} 6 \%$ WP, contains $25 \times 10^{6}$ cell / g of bacterium (Bacillus megaterium).

- Dipel ${ }^{\circledR} 6.4 \%$ WG, containing 32,000 clu /mg of bacterium (Bacillus thuringiensis var. kurstaki).

The nematode inoculation: The tomato plants were infected with root-knot nematode eggs which isolated from the infested roots of the eggplant (Solanum melongena L.) that obtained from Rashid region, Behera Governorate, Egypt. Sodium hypochlorite $(\mathrm{NaOCl})$ was utilized for isolation of nematode eggs from root galls according to Hussey and Barker (1973). Moreover, the roots were stained for 15 minutes in an aqueous solution of Phloxine B stain to detect the presence of nematode egg masses (Holbrook et al., 1983).

The Pots experiment: The pot experiment was carried out using tomato plants cv. super strain $\mathrm{B}$, the Pots were $15 \mathrm{~cm}$ in diameter and $20 \mathrm{~cm}$ in depth and each pot filled with $1 \mathrm{~kg}$ of autoclaved artificial mixture soil \{1clay: 2 sand $(\mathrm{v} / \mathrm{v})\}$. The isolated eggs of root-knot nematode were applied at the rate of 5000 eggs / pot. Six treatments were applied, next to untreated check and each treatment was replicated five times, and each replicate contains one plantlet. Fifty days after planting, the seedlings were uprooted and root systems were assessed for galling (number of galls/root system), and egg masses/root system, in addition to the shoot length, shoot weight, root length and root weight.

Application of eco-biorational products: The tested products were applied to soil as one-time drench according to the recommended dose as following: Bio Zeid ${ }^{\circledR}$ applied at the rate of $40 \mathrm{~kg} /$ fed; Bio $\operatorname{Arc}^{\circledR}$ utilized at $40 \mathrm{~kg} / \mathrm{fed}$; Stanes sting ${ }^{\circledR}$ at the rate of $1 \mathrm{~L} / 100 \mathrm{~L}$ water; Bio-Nematon ${ }^{\circledR}$ at the rate of $1.2 \mathrm{~kg} / 100 \mathrm{~L}$ water and Nemathorin ${ }^{\circledR}$ at the rate of $12.5 \mathrm{~kg} /$ fed. While, the suggested dose of Dipel ${ }^{\circledR}$ was $3 \mathrm{~kg} /$ fed. All treatments were applied two days after infection. The tomato plants were fertilized by (N: P: K 18:18:18 + TE).

Statistical analysis: Data of the present study were analyzed using variance test (ANOVA). The experimental design was a complete randomized design. The least significant differences (LSD) at the 5\% level of probability were determined using a computer program Costat software (1988).

\section{RESULTS}

The impact of certain eco-biorational products on galls and egg masses formation were recorded in Table (1) and Fig. (1). The obtained results revealed that all treatments reduce the galls without any significant differences. $B$. thuringiensis reduced the gall formation by $71.60 \%$, followed by B.subtilis, P. lilacinus, $B$. megaterium, T. album and fosthiazate that recorded $60.94,58.58,57.98,52.65$ and $51.50 \%$ reduction, respectively.

On the other hand, $B$. thuringiensis proved to be the most effective treatment which minified the egg masses by $77.78 \%$, followed by P. lilacinus, T. album, B. subtilis, fosthiazate and B. megaterium which recorded 65.18, $63.33,62.96,59.27$ and $57.04 \%$ reduction, consecutively. According to obtained data it was found that all treatments increased the shoot system growth significantly as compared with untreated check as shown in table 2. There were no significant differences on shoot height among all treatments in comparison with untreated check.

Table 1 . The effect of treatments on mean numbers of galls and egg masses.

\begin{tabular}{lcc}
\hline Treatments & Mean no. of galls / root system & Mean no. of egg masses/ root system \\
\hline P. lilacinus & $23.33 \mathrm{~b}$ & $15.67 \mathrm{~b}$ \\
T. album & $23.67 \mathrm{~b}$ & $19.33 \mathrm{~b}$ \\
B. megaterium & $26.67 \mathrm{~b}$ & $16.50 \mathrm{~b}$ \\
B. subtilis & $22.00 \mathrm{~b}$ & $16.67 \mathrm{~b}$ \\
B. thuringiensis & $16.00 \mathrm{~b}$ & $10.00 \mathrm{c}$ \\
fosthiazate & $27.33 \mathrm{~b}$ & $18.33 \mathrm{~b}$ \\
Untreated check & $56.33 \mathrm{a}$ & $45.00 \mathrm{a}$ \\
\hline
\end{tabular}

Within a column, numbers followed by different letter(s) are significantly different using LSD at $\mathrm{p}=0.05$. 
ESci J. Plant Pathol. 02 (02) 2013. 84-91

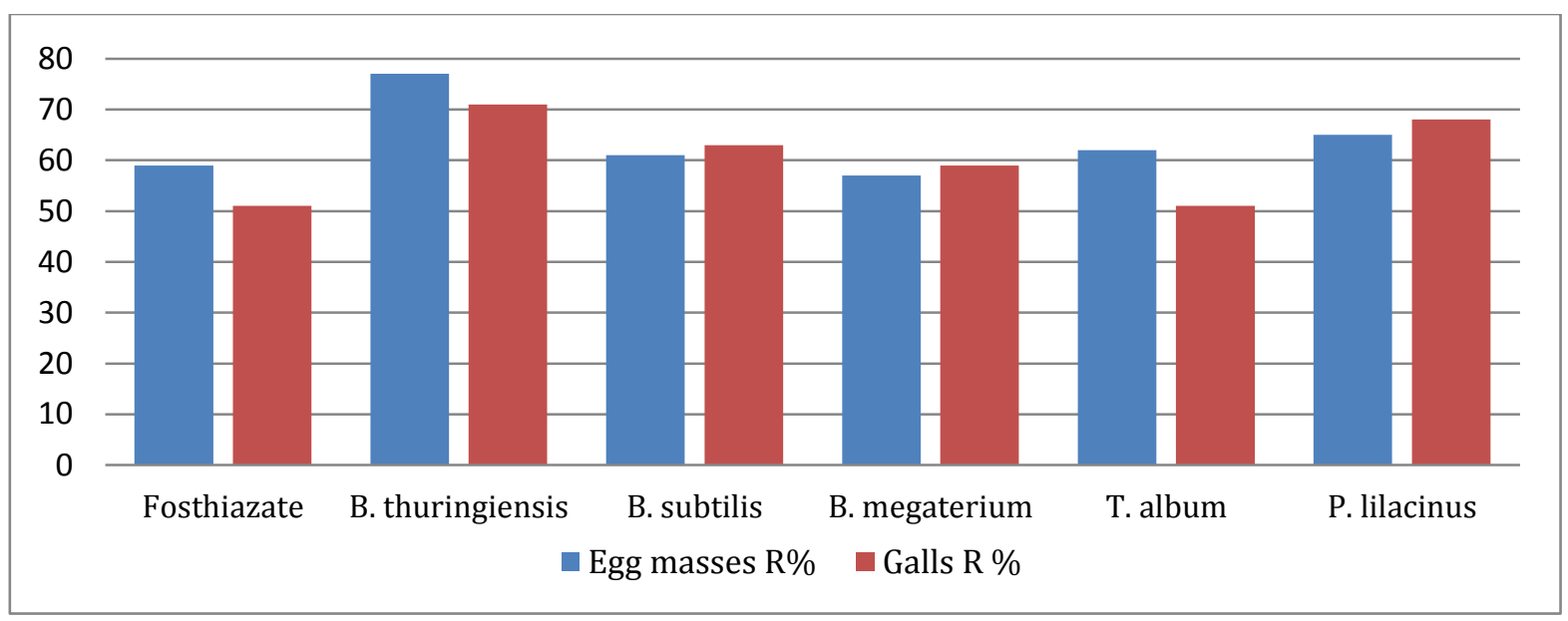

Fig. (1): the reduction percentage (R\%) of bio-products on galls and egg masses.

B.thuringiensis was the best treatment which recorded $90.44 \%$ augmentation, followed by $P$. lilacinus, fosthiazate, T. album, B. megaterium and B. subtilis achieving 89.60, 89.21, 86.99, 77.25 and $75.96 \%$ increasing, respectively. Moreover, B. thuringiensis increased shoot weight by $53.10 \%$, followed by $P$. lilacinus, B. megaterium, T. album, B. subtilis, next to fosthiazate with increasing values 35.03, 35.03, 25.92 and $23.03 \%$, respectively.

In respect to the effects of bio-products on the root system growth it were also recorded in table (3). $P$. lilacinus and B. thuringiensis showed the largest increase in root length with 59.49 and $43.14 \%$, consecutively. Meanwhile, B. megaterium, B. subtilis and fosthiazate increased the root length by $35.96,33.33$ and $25.5 \%$, respectively.

The antagonistic bacteria $B$. thuringiensis and $B$. megaterium were increased the root weight by 57.78 and $50 \%$, consecutively, followed by T. album, B. subtilis and P. lilacinus with $28.61,7.22$ and $2.78 \%$ increasing, respectively. While fosthiazate was the minimal treatment which reduced root weight by $2.78 \%$.

Table 2 . The effect of bio-products on plant shoot growth characteristics.

\begin{tabular}{lcccc}
\hline Treatments & Shoot height $\mathbf{( c m )}$ & I \% & Shoot weight $\mathbf{( g )}$ & I \% \\
\hline P. lilacinus & $48.67 \mathrm{a}^{\#}$ & $89.60^{*}$ & $16.48 \mathrm{ab}$ & 37.80 \\
T. album & $48.00 \mathrm{a}$ & 86.99 & $16.15 \mathrm{~b}$ & 35.03 \\
B. megaterium & $45.50 \mathrm{a}$ & 77.25 & $16.15 \mathrm{~b}$ & 35.03 \\
B. subtilis & $45.17 \mathrm{a}$ & 75.96 & $15.06 \mathrm{~b}$ & 25.92 \\
B. thuringiensis & $49.00 \mathrm{a}$ & 90.44 & $18.31 \mathrm{a}$ & 53.10 \\
fosthiazate & $48.57 \mathrm{a}$ & 89.21 & $14.72 \mathrm{~b}$ & 23.03 \\
Untreated check & $25.67 \mathrm{~b}$ & - & $11.96 \mathrm{c}$ & - \\
\hline
\end{tabular}

Within a column, numbers followed by different letter(s) are significantly different using LSD at $p=0.05$,

* Increasing percentages.

Table 3. The effect of bio-products on plant roots' growth indices.

\begin{tabular}{lcccc}
\hline Treatments & Root length (cm) & I \% & Root weight (g) & I \% \\
\hline P. lilacinus & $40.67 \mathrm{a}^{\#}$ & $59.49^{*}$ & $3.69 \mathrm{~cd}$ & 2.78 \\
T. album & $28.17 \mathrm{~cd}$ & 10.50 & $4.63 \mathrm{bc}$ & 28.61 \\
B. megaterium & $34.67 \mathrm{~b}$ & 35.96 & $5.40 \mathrm{ab}$ & 50.00 \\
B. subtilis & $34.00 \mathrm{~b}$ & 33.33 & $3.86 \mathrm{~cd}$ & 7.22 \\
B. thuringiensis & $36.5 \mathrm{ab}$ & 43.14 & $5.68 \mathrm{a}$ & 57.78 \\
fosthiazate & $32.00 \mathrm{bc}$ & 25.5 & $3.50 \mathrm{~d}$ & -2.78 \\
Untreated check & $25.50 \mathrm{~d}$ & - & $3.60 \mathrm{~d}$ & - \\
\hline
\end{tabular}

\#Within a column, numbers followed by different letter(s) are significantly different using LSD at $\mathrm{p}=0.05$

* Increasing percentages. 


\section{DISCUSSION}

According to this study, the efficiency of tested ecobiorational products which can reduce the reproduction of root-knot nematode were seen by the suppressing of the galls and egg masses formation and enhancement of plant growth. B. subtilis and B. thuringiensis are considered the most well-studied bacteria against plant parasitic nematodes (Crickmore et al., 1998; Dawar et al., 2008; Radnedge et al., 2003; Radwan, 2007; Siddiqui and Mahmood, 1999).

Ashoub and Amara (2010) investigated certain isolates of $B$. thuringiensis and $P$. fluorescens in vivo and in vitro against Meloidogyne incognita, and their results indicated that all $B$. thuringiensis isolates reduced galls formation by 81.8 and $94.6 \%$, and egg masses by 87.7 and 93.9\%, respectively, in vivo. Also, Prakob et al. (2009) found that B. subtilis, $P$. aeruginosa and $P$. lilacinus decreased nematode population densities, suppressed nematode infection and galls on lettuce roots and increased the weight of lettuce plants. In addition, Khalil et al. (2012b) found that formulated B. subtilis caused reduction for both galls and egg masses by 53.64 and $71.76 \%$, respectively.

Several reports clarified that the basic mechanisms of $B$. subtilis included direct parasitism, production of extracellular antibiotics metabolites or catabolic enzymes (e.g. proteases, chitinases and glucanases), stimulation of host defenses, incensement of plant growth, induced systemic resistance in plants, suppression of the plant diseases and secreting volatile nematicidal substances (Huang et al., 2009; Huang et al., 2005b; Ji et al., 2006; Kloepper and Ryu, 2006; Lahlali et al., 2013; Siddiqui and Mahmood 1999; St Leger, 1995).

On the other hand, Mena et al. (1996) recorded that the B. thuringiensis var. kurstaki controlled M. incognita and Radopholus similis Cobb on Cucurbita pepo. While, Radwan (1999) observed that the shoot and root length and fresh weight of tomato plants were increased in the presence of $B$. thuringiensis var. kurstaki and Oxamyl.

B. thuringiensis (Bt) produces one or more parasporal crystal inclusions (Cry or d-endotoxins). These toxins are known to be toxic to a wide range of insect species (Feitelson et al., 1992). Some Cry proteins are also toxic to nematodes (Feitelson et al., 1992). To date, five Cry proteins (Cry5B, Cry6A, Cry13, Cry14A, Cry21A) known to be toxic to larvae of a number of free-living or parasitic nematodes (Crickmore et al., 1998; Marroquin et al., 2000 and Wei et al., 2003). Additionally, a number of studies have reported direct antagonistic effects of other bacteria to pathogenic nematodes belonging to the genera Heterodera and Meloidogyne, included $B$. amyloliquefaciens, $B$. cereus, $B$. licheniformis, $B$. megaterium and $B$. thuringiensis.

In surveys have been conducted worldwide to detect fungal parasites of Meloidogyne spp. was found that there are more than 30 genera and 80 species of fungi such as Arthrobotrys spp., Monacrosporium spp., Fusarium spp., Aspergillus spp., Penicillium spp., $P$. lilacinus and Verticillium chlamydosporium, (Chen et al., 1996a; Godoy et al., 1983; Li et al., 1994; Roccuzzo et al., 1993 and Wang et al., 2001). However, in China, the predominant fungal species which collected from plant roots and infested soil was P. lilacinus that represented $49.3 \%$ of the isolates during a survey (Sun et al., 2006).

The antagonistic fungus $P$. lilacinus proved its activity against root-knot nematodes on varied crops. Several reports clarified that using formulated $P$. lilacinus reduced the formation of galls and egg masses (Udo et al., 2013). Meanwhile, Khalil et al. (2012b) confirmed that liquid Bio-Nematon ${ }^{\circledR}$ (P. lilacinus) and Dipel $2 \mathrm{x}^{\circledR}$ (B.thuringiensis var. kurstaki), were the most effective treatments which suppressed the galls by 66.67 and $60.15 \%$, respectively, while decreased the egg masses by $75.97 \%$ and $74.97 \%$, consecutively.

Also, Kiewnick and Sikora (2006) recorded that the fungal biocontrol agent, P. lilacinus strain 251 (PL251) was potential to control the root-knot nematode Meloidogyne incognita on tomato. The pre-planting soil treatment reduced root galling by $66 \%$ and number of egg masses by $74 \%$. P. lilacinus was effective against the root knot nematode and significantly reduced the galls number, egg masses and eggs per egg mass. Moreover, the enhancement of plant growth (Ganaie and Khan, 2010; Oclarit et al., 2009; Prakob et al., 2007 and Siddiqui et al., 2001).

The action of $P$. lilacinus against plant parasitic nematodes was interpreted in multitude investigations. Khan et al. (2006b) and Khan et al. (2004) recorded the directed penetration of fungal hypha to the female cuticle of $M$. javanica by transmission electron microscopy. While, Park et al. (2004) reported that $P$. lilacinus could be produce leucino toxin and other nematicidal compounds. In the laboratory test this fungus infested eggs of $M$. incognita and destroys the embryos within 5 days because of simple penetration of 
the egg cuticle by individual hypha aided by mechanical and/or enzymatic activities, in addition to killing juveniles and females of $M$. incognita and Globodera pallida (Jatala, 1986). It was mentioned that P. lilacinus caused substantial egg deformation in M. incognita, these deformed eggs never matured or hatched (Jatala et al., 1985) . The serine protease produced by $P$. lilacinus might play a role in penetration of the fungus through the egg shell of the nematode (Bonants et al., 1995 and Khan et al., 2004).

Also, it was reported that T.viride reduced galls formation and egg masses of Meloidogyne incognita, infecting Okra (Kumar et al., 2012). Le et al. (2009) investigated the potential of Fusarium and Trichoderma isolates against $M$. graminicola in rice. The results showed that Trichoderma isolates reduced galls formation up to $38 \%$, while Fusarium isolates reduced the galls by $29-42 \%$. Furthermore, Krishnaveni and Subramanian (2004) and Sharma (1999) indicated that T. harzianum, T. viride and P. fluorescens were effective in controlling the plant parasitic nematodes. Kavitha et al. (2007) found that P. fluorescens, B. subtilis and T. viride showed a significant increase in the plant growth parameters. However, the phytonematodes are affecting the Trichoderma spp. through the production of volatile and nonvolatile toxic metabolites, antibiotics, viridin, viridian, gliovirin, glisoprenins, heptelidic acid and others (Vey et al., 2001). Fosthiazate which belong to organophosphate group is inhibit the acetylcholine esterase (AChE) in various parts of the nervous system of nematodes and provides a highly performance as systemic nematicide. The results in this study are in agreement with those obtained by other researcher (Giannakou et al., 2005; Pathan et al., 2005; Russo, et al., 2003; Saad et al., 2011) who found that fosthiazate was effective against RKN.

Besides, Radwan et al., (2012) confirmed that fosthiazate was the most effective treatment against the root galls formation in compared with four granular nematicides namely, cadusafos, carbofuran, ethoprop and oxamyl. Also, all treatments increased the plant growth indices. Whilst, Kesba (2011) found that nemathorin ${ }^{\circledR} 10 \%$ G (fosthiazate) was the superior treatment which reduced the galls and egg masses between all other treatments.

\section{CONCLUSION:}

It could be concluded that application of formulated ecobiorational products were effective against the reproduction of RKN and proved the plant health.

\section{LITERATURE CITED}

Ashoub, A. H. and M. T. Amara. 2010. Biocontrol activity of some bacterial genera against root-knot nematode, Meloidogyne incognita. J. Ameri. Sci. 6: 321- 328.

Atkins, S. D., I. M. Clark, S. Pande, P. R. Hirsch and B. K. Kerry. 2005. The use of real-time PCR and speciesspecific primers for the identification and monitoring of Paecilomyces lilacinus. FEMS Microbiol. Ecol. 51: 257-264.

Atkinson, H. J., C. J. Lilley and P. E. Urwin. 2012. Strategies for transgenic nematode control in developed and developing world crops. Food Biotechnol. Plant Biotechnol. 23: 251-256.

Bonants, P. J. M., P. F. L. Fitters, H. Thijs, E. D. Belder, C. Waalwijik and J. W. D. M. Henfling. 1995. A basic serine protease from Paecilomyces lilacinus with biological activity against Meloidogyne hapla eggs. Microbiol.141: 775-784.

Chen, S. Y., D. W. Dickson and E. B. Whitty. 1996a. Fungi associated with egg masses of Meloidogyne incognita and M. javanica in a Florida tobacco Weld. Nematro. 26: 153-157.

Costat Software. 1988. Microcomputer Program Analysis. CoHort software, Berkely, CA, USA.

Crickmore, N., D. R. Zeigler, J. Feitelson, E. Schnepf, J. V. Rie, D. Lereclus, J. Baum and D. H. Dean. 1998. Review of the nomenclature for the Bacillus thuringiensis pesticidal crystal proteins. Microbiol. Mol. Biol. Rev. 62: 807-813.

Dawar, S., M. Tariq and M. J. Zaki. 2008. Application of Bacillus species in control of Meloidogyne javanica (Treub) Chitwood on cowpea and mash bean. Pak. J. Bota. 40: 439-444.

Fettelson, J., J. Payne and I. Kim.1992. Bacillus thuringiensis: insects and beyond. Biotechnol. 10: 271-275.

Ganaie, M. A. and T. A. Khan. 2010. Biological potential of Paecilomyces lilacinus of pathogenesis of Meloidogyne incognita infecting tomato plants. Euro. J. Appl. Sci. 2: 80-84.

Giannakou, I. O., D. G. Karpouzas, I. Anastasiades, N. G. Tsiropoulos and A. Georgiadou. 2005. Factors affecting the efficacy of non-fumigant nematicides for controlling root-knot nematodes. Pest Manag. Sci. 61: 961-972.

Godoy, G., R. Rodríguez-kábana and G. Morgan-jones. 
1983. Fungal parasites of Meloidogyne arenaria eggs in an Alabama soil. A mycological survey and greenhouse studies. Nematro. 13: 201-213.

Holbrook, C. C., D. A. Knauft and D. W. Dikson. 1983. A technique for screening peanut for resistance to Meloidogyne arenaria. Plant Dis. 57: 957-958.

Howeedy, A., N. G. henna, A. Shawkey and F. Abdel-Aziz. 2003. Tomato production and cultivate. Technique Bulletin No. 816 of Agricultural Research Center. pp. 84.

Huang, X. W., N. H. Zhao and K. Q. Zhang. 2005b. Extracellular enzymes serving as virulence factors in nematophagous fungi involved in infection of the host. Res. Microbiol. 115: 811-816.

Huang, Y., C. Xu, L. Ma, K. Zhang, C. Duan and M. Mo. 2009. Characterisation of volatiles produced from Bacillus megaterium YFM3.25 and their nematicidal activity against Meloidogyne incognita. Euro. J. Plant Pathol. 26: 417-422.

Hussey, R. S. and K. R. Barker. 1973. A comparison of methods of collecting inocula on Meloidogyne pp., including a new technique. Plant Dis. Rep. 57:1025-1028.

Jatala, P. 1986. Biological control of plant parasitic nematodes. Ann. Rev. Phytopathol. 24: 453-489.

Jatala, P., O. J. Franc, A. Gonzales and C. M. O’Hara. 1985. Hatching stimulation and inhibition of Globodera pallid eggs by enzymatic and exopathic toxic compounds of some biocontrol fungi. J. Nematol. 17: 501.

Ji, P., H. Campbell, J. Kloepper, J. Jones, T. Suslow and M. Wilson. 2006. Integrated biological control of bacterial speck and spot of tomato under field conditions using foliar biological control agents and plant growth promoting rhizobacteria. Biol. Cont. 36: 358-367.

Karanja, N. K., G. K. Mutua and J. W. Kimenju. 2007. Evaluating the effect of Bacillus and Rhizobium bio-inoculant on nodulation and nematode control in Phaseolus vulgaris L. In: Advances in Integrated Soil Fertility Research in Sub-Saharan Africa: Challenges and Opportunities, (Bationo, A., B. Waswa, J. Kihara and J. Kimetu eds.), Springer, Netherlands, 863-868 PP.

Kavitha, J., E. I. Jonathan and R. Umamaheswari. 2007. Field application of Pseudomonas fluorescens, Bacillus subtilis and Trichoderma viride for the control of Meloidogyne incognita (Kofoid and
White) Chitwood on sugarbeet. J. Biol. Cont. 21: 211-215.

Kesba, H. H. 2011. Pathogenicity of Meloidogyne incognita on pepper and impact of some control measures . Interna. J. Nematol. 21: 203-209.

Khalil, M. S. 2013a. Alternative Approaches to Manage Plant Parasitic Nematodes. J. Plant Pathol. Microbiol. 4: e105. doi:10.4172/2157$7471.1000 \mathrm{e} 105$.

Khalil, M. S., A. Kenawy, M. A. Ghorab and E. E. Mohammed. 2012b. Impact of microbial agents on Meloidogyne incognita management and morphogenesis of tomato. J. Biopest. 5: 28-35.

Khan, A., K. L. Williams and H. K. M. Nevalainen. 2004. Effects of Paecilomyces lilacinus protease and chitinase on the egg shell structures and hatching of Meloidogyne javanica juveniles. Biol. Cont. 31: 346-352.

Khan, A., K. L. Williams and H. K. M. Nevalainen. 2006b. Infection of plant parasitic nematodes by Paecilomyces lilacinus and Monacrosporium lysipagum. Biol. Cont. 51: 659-678.

Kiewnick, S. and R. A. Sikora. 2006. Biological control of the root-knot nematode Meloidogyne incognita by Paecilomyces lilacinus strain 251. Biol. Cont. 38: 179-187.

Kloepper, J. W. and C. M. Ryu. 2006. Bacterial endophytes as elicitors of induced systemic resistance. In: Microbial root endophytes, Heildelberg, (Schulz, B., C. Boyle and T. Siebern eds.), Springer, Verlag, 33-51 PP.

Knowles, B. H. and J. A. T. Dow. 1993. The crystal $\delta$ endotoxins of Bacillus thuringiensis: models of their mechanism of action on the insect gut. Bioas. 15: 469-476.

Krishnaveni, M. and S. Subramanian. 2004. Evaluation of biocontrol agents for the management of Meloidogyne incognita on cucumber (Cucumis sativus L). Current Nematol. 15: 33-37.

Kumar, V., A. U. Singh and R. K. Jain. 2012.Comparative efficacy of bioagents as seed treatment for management of Meloidogyne incognita infecting okra. Nematol. medit. 40: 209-211.

Lahlali, R., G. Peng, B. D. Gossen, L. McGregor, F. Q. Yu, R. K. Hynes, S. F. Hwang, M. R. McDonald, and S. M. Boyetchko. 2013. Evidence that the Biofungicide Serenade (Bacillus subtilis) Suppresses Clubroot on Canola via Antibiosis and Induced Host 
Resistance. Biol. Cont. 103: 245-254.

Le, H. T. T., J. L. Padgham and R. A. Sikora. 2009. Biological control of the rice root-knot nematode Meloidogyne graminicola on rice, using endophytic and rhizosphere fungi. Interna. J. Pest Manag. 55: 31-36.

Li, T. F., L. P. Lei and M. Yang. 1994. Isolation and identification of natural enemies fungi of tobacco root-knot nematodes. Chinese Toba. 1: 22-24.

Marroquin, L. D., D. Elyassnia, J. S. Griffitts, J. S. Feitelson and R. V. Aroian. 2000. Bacillus thuringiensis (Bt) toxin susceptibility and isolation of resistance mutants in the nematode Caenorhabditis elegans. Genet. 155: 1693-1699.

Mena, J., R. Vaquez, M. Fernandez, L. Perez, M. Garcia, E. Pimentel, J. D. Mencho, Z. Zaldua, R. Garcia, D. Somontes and R. Moran. 1996. Use of Bacillus thuringiensis var. kurstaki to control Meloidogyne incognita and Radopholus similis. Centro Agrico. 23: 31-38.

Oclarit, E. L., C. Joseph, R. Cumagun. 2009. Evaluation of efficacy of Paecilomyces lilacinus as biological control agent of Meloidogyne incognita attacking tomato. J. Plant Protec. Res. 49: 337-340.

Park, J. O., , J. R. Hargreaves, , E. J. McConville, G. R. Stirling, E. L. Ghisal-berti, K. Sivasithamparam. 2004. Production of leucinostatins and nematicidal activity of Australian isolates of Paecilomyces lilacinus (Thom) Samson. Lett. Appl. Microbiol. 38: 271-276.

Pathan, M. A., S. H. Soomro, M. M. Jiskani, K. H. Wagan, JA Memon. 2005. Effect of Paecilomyces lilacinus and Furadan on plant growth, root nodulation and reproduction of Meloidogyne incognita in tomato. Pak. J. Nematol. 23:67-71.

Prakob, W., V. Kanthasab, V. Supina, N. Chaimeungchern and T. Kid-tayo. 2007. Use of arbuscular mycorrhizal fungi, antagonistic fungus and rhizobacteria $P$. aeruginosa and $B$. subtillis in controlling tomato root-knot nematodes. J. Agric. 23: 403-406.

Prakob, W., J. Nguen-Hom, P. Jaimasit, S. Silapapongpri, J. Thanunchai and P. Chaisuk. 2009. Biological control of lettuce root knot disease by use of Pseudomonas aeruginosa, Bacillus subtilis and Paecilomyces lilacinus. J. Agri. Techno. 5: 179-191.

Radnedge, L., P. G. Agron, K. K. Hill, P. J. Jackson, L. O. Ticknor, P. Keim and G. L. Andersen. 2003.
Genome differences that distinguish Bacillus anthracis from Bacillus cereus and Bacillus thuringiensis. Appl. Environ. Microbiol. 69: 27552764.

Radwan, M. A. 2007. Bioactivity of commercial products of Bacillus thuringiensis on Meloidogyne incognita infecting tomato. Ind. J. Nematol. 37: 30-33.

Radwan, M. A. 1999. An integrated control trial of Meloidogyne incognita using Bacillus thuringiensis associated with nematicides. J. pest cont. environ. Sci. 7:103-114.

Radwan, M. A., S. A. A. Farrag, M. M. Abu-Elamayem and N. S. Ahmed. 2012. Biological control of the rootknot nematode, Meloidogyne incognita on tomato using bioproducts of microbial origin. App. Soil Eco. 56: 58-62.

Randhawa, N., P. K. Sakhuja and I. Singh. 2001. Management of root-knot nematode Meloidogyne incognita in tomato with organic amendments. Plant Dis. Res. 16: 274-276.

Roccuzzo, G., A. Ciancio and R. Bonsignore. 1993. Population density and soil antagonists of Meloidogyne hapla infecting kiwi in southern Italy. Fundam. Appl. Nematol. 16: 151-154.

Russo, G., A. Loffredo, G. Fiume, F. Fiume. 2003. Efficacy of oxamyl alone or integrated against nematodes. Informa. Agra. 59:56-58.

Saad, A. S. A., M. A. Massoud, H. S. Ibrahim and M. S. Khalil. 2011. Management study for the root- knot nematodes, Meloidogyne incognita on tomatoes using fosthiazate and arbuscular mycorrhizal fungus. J. Adv. Agri. Res. 16: 137-147.

Sakhuja, P. K. and R. K. Jain. 2001. Nematode diseases of vegetable crops and their management. In: Diseases of Fruits and Vegetables and their Management. (Thind, T. S. ed.), Kalyani Pub., Ludhiana, India, $474 \mathrm{P}$.

Sharma, D. D. 1999. Effect of culture filtrates of biocontrol agents on larval mortality of Meloidogyne incognita, in comparison with Rugby 10G. Ind. J. Sericul. 38: 152-154.

Siddiqui, I. A., A. Zareen, S. S. Shauket and M. J. Zaki. 2001. Evaluation of Rhizobia for control of Meloidogyne javanica in Vigna mungo. Pak. J. Biol. Sci. 4: 1124-1125.

Siddiqui, Z. A. and I. Mahmood. 1999. Role of bacteria in the management of plant parasitic nematodes: A review. Bioreso. Technol. 69: 167-179. 
St Leger, R. J. 1995. The role of cuticle-degrading proteases in fungal pathogenesis of insects. Can. J. Bot. 73: 1119-1125.

Sun, M., L. Gao, Y. Shi, B. Li, X. Liu. 2006. Fungi and actinomycetes associated with Meloidogyne spp. Eggs and females in China and their biocontrol potential. J. Invert. Pathol. 93: 22-28.

Thangavelu R. and M.M. Mustaffa. 2012. Current Advances in the Fusarium Wilt Disease Management in Banana with Emphasis on Biological Control. Plant Pathol. 273-298.

Udo, I. A., M. I. Uguru, R. O. gbuji. 2013. Pathogenicity of Meloidogyne incognita race1 on tomato as influenced by different arbuscular mycorrhizal fungi and bioformulated Paecilomyces lilacinus a dysteric cambisol soil. J. Plant Protec. Res. 53:7178.

Vey, A., R. E. Hoagland and T. M. Butt. 2001. Toxic metabolites of fungal biocontrol agents. In: Fungi as biocontrol agents: Progress, problems and potential, (Butt, T. M., C. Jackson and N. Magan eds.). CAB International Bristol, pp 311-346.

Wang, L.F., B. J. Yang and C. D. Li. 2001. Investigation of parasitic fungi on root-knot nematodes in East China. Mycosyst. 20: 264-267.

Wei, J. Z., K. Hale, L. Carta, E. Platzer, C. Wong, S. C. Fang and R. V. Aroian. 2003. Bacillus thuringiensis crystal proteins that target nematodes. In: Proceedings of National Academy of Sciences, USA, 100: 2760- 2765. 